\title{
Comparative analysis of zoosporogenesis' genes of the bastoclad Blastocladiella emersonii and the aphelid Paraphelidium tribonematis reveals the new directions of evolutionary research
}

\author{
Igor R. Pozdnyakov ${ }^{1}$, Andrey V. Zolotarev ${ }^{1}$ and \\ Sergey A. Karpov ${ }^{1,2}$ \\ ${ }^{1}$ Zoological Institute of Russian Academy of Science, St. Petersburg, 199034, Russia \\ ${ }^{2}$ St. Petersburg State University, Biological Faculty, St. Petersburg, 199034, Russia
}

| Submitted November 13, 2020 | Accepted February 15, 2021 |

\begin{abstract}
Summary
The aphelids, intracellular parasitoids of algae, have a life cycle similar to zoosporic fungi Chytridiomycota and Blastocladiomycota, and are positioned as a sister clade to all fungi on the recent multigene phylogenetic tree. The fungi and aphelids might possibly have a common ancestor with a complex life cycle somewhat similar to modern zoosporic fungi. To investigate this possibility we have analyzed the genes that increase expression during zoosporogenesis of the blastoclad fungus Blastocladiella emersonii based on the transcriptomic data of Vieira and Gomes (2013), and described the course of sporogenesis at the molecular level. Homologs of genes from the B. emersonii gene set were found in various lineages of the Opisthokonta group, and specifically in the transcriptome of Paraphelidium tribonematis. We calculated the percentage ratios of genes that formed common functional groups and the genes with homologs in various clades of related organisms. We found that zoospore production of a blastoclad fungus is a multi-phase process, where switching of the regulatory elements takes place. The analyzed genes are distributed as follows: $81 \%$ are common for all Opisthokonta, $16 \%$ are specific for Fungi and only $3 \%$ are common to Fungi and aphelids but none are found in the Holozoa lineage. Based on these data we propose a hypothesis on the independent origin of the life cycle in Fungi and Aphelida from a polymorphic ancestor.
\end{abstract}

Key words: Holomycota, zoospore, Blastocladiella, Aphelida, morphogenesis, life cycle, genetic regulation

\section{Introduction}

The group Opisthokonta is known for its inclusion of two well-known groups of multicellular organisms (Niklas and Newman, 2013; Sebé-Pedrós et al., 2017): multicellular animals (Sebé-Pedrós et al., 2017; Brunet and King, 2017) and fungi (Sebé-Pedrós et al., 2017; Nagy et al., 2018). Both groups are characterized by the so-called complex multicellularity (Niklas and Newman, 2013) altho- 
ugh the two lineages of heterotrophic organisms have fundamentally differing structure, physiology, and mechanisms of formation and maintenance of multicellularity. Moreover, according to the latest data, complex multicellularity in the fungal lineage has occured independently from 8 to 11 times (Nagy et al., 2018). These facts have prompted a search among the wide range of unicellular members of the Opisthokonta for fundamental features that may have given rise to multicellularity (Adl et al., 2019). Here, comparison of the fungal (Holomycota) and animal (Holozoa) evolutionary lineages could reveal whether animal and fungal multicellularity have something in common at the molecular level (Schulze et al., 1994; Sebé-Pedrós et al., 2010), and whether unicellular opisthokonts have genetic systems that serve as universal pre-adaptations for multicellularity (Niklas and Newman, 2013; van Gestel and Tarnita, 2017).

For multicellular animals, there is some justification for the concept of a unicellular ancestor with a complex life cycle serving as a precursor for further cellular differentiation (Sebé-Pedrós et al., 2017; van Gestel and Tarnita, 2017). The arguments supporting this hypothesis are as follows: 1) many unicellular opisthokonts have complex, multi-stage life cycles (Mikhailov et al., 2009; Sebé-Pedrós et al., 2017).; 2) an abundance of genes associated with the key processes in the functioning of multicellularity have been found in unicellular opisthokonts (Burkhardt, 2015; Cai, 2008; Fairclough et al., 2013; King et al., 2008; Nichols, 2012; Ruiz-Trillo et al., 2007; SebéPedrós et al., 2013; Tikhonenkov et al., 2019, 2020); 3 ) there are a number of parallels between metazoan cell differentiation and differentiation of the various stages in the complex life cycles of protists (Brunet and King, 2017; Michailov et al., 2009; van Gestel and Tarnita, 2017; Sebé-Pedrós et al., 2017). In some hypotheses, not only is cell differentiation, but also larval development, the basic element of the original metazoan life cycle, which could be derived from the complex life cycle of a unicellular ancestor (Mikhailov et al., 2009).

This concept attracts research interest in the morphogenetic processes in different Opisthokonta, particularly unicellular members located basally on the opisthokont phylogenetic tree (Nagy et al., 2018; Ruiz-Trillo, 2007; Sebé-Pedrós et al., 2017). It is probable that some morphogenetic programs of ancestors of the entire opisthokont lineage, or of its different sub-lineages, could serve as the basic core for morphogenetic programs of more advanced organisms, including those with complex multicellularity (de Mendoza et al., 2013).

This work focuses on the analysis of genes of the blastoclad fungus Blastocladiella emersonii. The material for analysis has been taken from the article 'Global analysis of gene expression during sporulation of the aquatic fungus Blastocladiella emersonii' (Vieira and Gomes, 2013), where the relative levels of gene expression and gene annotation are provided. The authors of this article performed large-scale gene analyses within the entire life cycle, grouping genes on the basis of their general function and in accordance with their expression profiles. As a result, they showed the dynamics of a few gene clusters and the general dynamics of their main processes of cell physiology that are composed from the dynamics of gene majorities in every functional group.

At the same time, the authors of the article obtained data on gene expression at several time points throughout each stage of the life cycle. Therefore, the information contained in the article allows us to make an additional analysis and thereby consider the course of each of the stages separately at the molecular level.

The first purpose of our analysis was to describe the course of zoosporogenesis. For this we divided sporogenesis into phases according to the main physiological processes observed and based on this we have been able to highlight the main features of each selected phase.

The second aim was to search for homologs of the selected genes in various lineages of the opisthokonts and specifically in the transcriptome of Paraphelidium tribonematis (Aphelida). The transcriptome and the predicted proteome (translated transcriptome) data of $P$. tribonematis were taken from the published global transcriptome analysis of this aphelid (Torruella et al., 2018).

Here, we draw some primary conclusions based on the comparative analyses of gene expression throughout the life cycles of blastocladiomycetes, aphelids, and selected groups of Holomycota.

\section{Material and methods}

Analyzed data of differential gene expression were obtained by the authors of the original article using cultures in which they artificially induced zoosporogenesis (Vieira and Gomes, 2013). For the mRNA transcripts the complementary DNAs 
(cDNAs) were obtained at the time points 60, 120 and $150 \mathrm{~min}$. The authors did not clarify correspondence between different cellular phenotypes and time points of sample collections. Comparisons with the studies of $B$. emersonii sporulation show that noted time points do not correspond to precise times of phenotype switching (da Silva et al., 1986; Peralta and Lodi, 1988). The time point 60 min corresponds to the formation of septa, 120 and 150 min should correspond to the papillate zoosporangium. All three time points of the original work trace the cell condition at the unicellular multinuclear stage.

In our study, the IDs of the analyzed genes were obtained from the NCBI (National Centre for Biotechnology Information) database and their annotation and expression levels are recorded in level values were taken from Supplementary Table 1 of the original article. We selected the set of genes reaching their maximal expression level in one of the three time points of the zoosporogenesis (at 60, 120 or 150 minutes). The nucleotide sequences of the cDNAs in FASTA format were downloaded from the NCBI site. For seven IDs, no sequences were found in the NCBI database.

In general, our study had three different though interrelated tasks.

The first task was to identify homologs of the analyzed genes in the $P$. tribonematis transcriptome. We used a predicted proteome of $P$. tribonematis based on transcriptome translation (Torruella et al., 2018) as the homolog search database. The search tool was the BLASTX console application, and an e-value threshold of 0.01 was set for the search. If several $P$. tribonematis protein sequences were aligned on one nucleotide sequence of $B$. emersonii, the sequence with the maximum bit score was selected as the corresponding one. The revealed homology between sequences of $B$. emersonii and P. tribonematis was verified by the bidirectional BLAST method. We obtained $100 \%$ confirmation for the selected B. emersonii sequences. Consequently, among the analyzed genes, we identified genes that did and did not have homologs in the P. tribonematis transcriptome.

For the genes that did not have homologs in the $P$. tribonematis transcriptome, homologs were searched for in the entire Opisthokonta group using the online version of the BLASTX search tool; the e-value threshold was 0.01 . The search was performed on the NCBI database 'non-redundant protein sequences' with the selected group 'Opisthokonta' as the organism. For several genes there were no homologs in Opisthokonta. For such sequences, a control search was performed using BLASTn (e-value threshold $=0.001$, megablast task) in the database 'Whole-genome shotgun contigs'. The control search results were consistent with the search in the protein database. For sequences whose homologs were not found in the protein database, no homologs were found in the nucleotide database either. B. emersonii sequences without any homologs in the Opisthokonta group were excluded from the analysis because they are most likely erroneous (the result of errors in mRNA sequencing and transcriptome assembly). It is likely that some of these sequences may encode species-specific proteins. However, in this case, these genes would also not be associated with the fundamental processes of zoospore production, and the result of the analysis would not depend on their exclusion.

In total, after excluding probably erroneous sequences from the analysis, genes recognized as valid for analysis were divided into two groups: with and without homologs in the P. tribonematis transcriptome. For each group, we calculated their proportion among the total number of valid analyzed genes. The same calculations were also made separately for valid genes with maximum expression at 60,120 and 150 minutes.

The second task was to identify the analyzed genes with homologs in the entire Opisthokonta group (including the Holozoa and Holomycota lineages), only in the Holomycota lineage, and exclusively in the Fungi lineage. To fulfil this aim, homologs for all valid analyzed genes were searched using BLASTX (online interface, e-value threshold $=0.01)$ in the database 'Non-redundant protein sequences'. The search was carried out in three stages:

1) Search among all 'Opisthokonta' to confirm the presence of homologs for all selected sequences.

2) Search among 'Opisthokonta', excluding organisms of the Holomycota lineage ('Nucleariida', 'Rozella', 'Microsporidia', 'Fungi', Aphelida) to reveal the genes with homologs only in this lineage.

3 ) For the genes selected in stage 2, homologs were searched for in the Holomycota lineages without 'Fungi' to identify the genes with homologs exclusively in the Fungi lineage.

The proportions of genes with homologs in certain lineages of related organisms were calculated among the total number of valid analyzed genes. The calculation was performed for all genes in general, and separately for genes with peak expression at 
Table 1. The numbers and proportions of genes recognized as valid for analysis, with and without homologs in the P. tribonematis and increased expression by $\geq 1.5$ times at selected time points.

\begin{tabular}{|c|c|c|c|c|c|c|c|c|}
\hline \multirow{2}{*}{ Described sequnces } & \multicolumn{2}{|c|}{$60 \mathrm{~min}$} & \multicolumn{2}{|c|}{$120 \mathrm{~min}$} & \multicolumn{2}{|c|}{$150 \mathrm{~min}$} & \multicolumn{2}{|c|}{ Total } \\
\hline & Number & Percentage & Number & Percentage & Number & Percentage & Number & Percentage \\
\hline $\begin{array}{l}\text { Total with maximal } \\
\text { expression }\end{array}$ & 95 & & 112 & & 150 & & 357 & \\
\hline $\begin{array}{l}\text { Sequence not found } \\
\text { in NCBI database }\end{array}$ & 4 & & - & & 3 & & 7 & \\
\hline $\begin{array}{l}\text { Homologs not found } \\
\text { in NCBI database }\end{array}$ & 19 & & 22 & & 48 & & 89 & \\
\hline $\begin{array}{l}\text { Recognized as valid } \\
\text { for analysis }\end{array}$ & 72 & & 90 & & 99 & & 261 & \\
\hline $\begin{array}{l}\text { With homologs in } \\
\text { the P. tribonematis } \\
\text { transcriptome }\end{array}$ & 59 & $\begin{array}{l}82 \% \\
\text { (of } 72 \text { ) }\end{array}$ & 76 & $\begin{array}{l}84.5 \% \\
\text { (of } 90 \text { ) }\end{array}$ & 69 & $\begin{array}{l}70 \% \\
\text { (of } 99 \text { ) }\end{array}$ & 204 & $\begin{array}{c}78 \% \\
\text { (of } 261 \text { ) }\end{array}$ \\
\hline $\begin{array}{l}\text { Without homologs in } \\
\text { the P. tribonematis } \\
\text { transcriptome }\end{array}$ & 13 & $\begin{array}{l}18 \% \\
\text { (of } 72 \text { ) }\end{array}$ & 14 & $\begin{array}{l}15.5 \% \\
\text { (of } 90 \text { ) }\end{array}$ & 30 & $\begin{array}{l}30 \% \\
\text { (of } 99 \text { ) }\end{array}$ & 57 & $\begin{array}{l}22 \% \\
\text { (of } 261 \text { ) }\end{array}$ \\
\hline $\begin{array}{l}\text { Increased expres- } \\
\text { sion by }>1.5 \text { times }\end{array}$ & 36 & $\begin{array}{l}50 \% \\
\text { (of } 72 \text { ) }\end{array}$ & 70 & $\begin{array}{l}78 \% \\
\text { (of } 90 \text { ) }\end{array}$ & 90 & $\begin{array}{l}90 \% \\
\text { (of } 99 \text { ) }\end{array}$ & 196 & $\begin{array}{c}75 \% \\
\text { (of } 261 \text { ) }\end{array}$ \\
\hline
\end{tabular}

60, 120 and 150 minutes. Calculations were also performed for each group of genes, i.e. those with and without homologs in the P. tribonematis transcriptome.

The third task was to describe the course of zoospore formation at the molecular level. It included the following actions:

- Describe the function of each of the proteins involved in the process and highlight the major functional groups of these proteins.

- Identify the steps of the process that differ from each other by the actions of the main functional groups.

- Describe the chain of changes and their regulation at each stage.

For this task, the genes with expression that increased by $\geq 1.5$ times were observed. This selection was used as a cut-off for the genes that do not have a significant effect and for the genes that are not involved in the process but whose expression changes under the non-specific influence of others.

Based on the homolog search, we added some annotations and annotation refinements to the protein annotations made by the authors of the original article (Vieira and Gomes, 2013). The protein functions were determined by their descriptions in databases, mainly UniProt, and by articles describing them, primarily from the NCBI database. Gene functions and expression levels were taken into account when describing the dynamics of activity.
For every time point $(60,120,150 \mathrm{~min})$, the number of genes in each functional group and their proportion among all observed genes were also calculated.

\section{Results}

Tables 1 and 2 show the numbers and percentages of genes with and without homologs in the P. tribonematis proteome; genes with homologs in the entire group Opisthokonta or only in Fungi, and genes whose expression increased by $\geq 1.5$ times.

Tables 3-5 (short versions) show the correspondence between the $B$. emersonii genes involved in zoospore production and their distribution according to functional group. The full versions of these tables, including the gene annotations, expression level values and IDs of $P$. tribonematis transcripts homologous to the $B$. emersonii genes are available as Supplementary materials (Tables 3-5 Supplementary).

Among the genes with maximum expression at $60 \mathrm{~min}, 36$ had $>1.5$ times increased expression level. Of these, $12(33 \%)$ are genes responsible for proteasome activity and protein breakdown. Six genes $(17 \%)$ are associated with protein synthesis, of which three control mRNA maturation and three control post-translational protein folding, including actin. Five genes (14.5\%) are involved in regulating redox potential. Two genes $(5.5 \%)$ affect 
Table 2. The numbers and proportions of genes with and without homologs in the P. tribonematis transcriptome, and among them, with homologs in the entire group Opisthokonta, Holomycota (without Holozoa), and only in the group Fungi. Genes with increased expression by $\geq 1.5$ times were observed.

\begin{tabular}{|c|c|c|c|c|c|c|c|c|}
\hline \multirow{2}{*}{ Described sequences } & \multicolumn{2}{|c|}{$60 \mathrm{~min}$} & \multicolumn{2}{|c|}{$120 \mathrm{~min}$} & \multicolumn{2}{|c|}{$150 \mathrm{~min}$} & \multicolumn{2}{|c|}{ Total } \\
\hline & Number & Percentage & Number & Percentage & Number & Percentage & Number & Percentage \\
\hline $\begin{array}{l}\text { Valid analysed genes } \\
\text { with increased } \\
\text { expression by }>1.5 \\
\text { times }\end{array}$ & 36 & & 70 & & 90 & & 196 & \\
\hline $\begin{array}{l}\text { With homologs in } \\
\text { the } \mathrm{P} \text {. tribonematis } \\
\text { transcriptome }\end{array}$ & 28 & $\begin{array}{l}78 \% \\
\text { (of } 36 \text { ) }\end{array}$ & 60 & $\begin{array}{l}86 \% \\
\text { (of } 70 \text { ) }\end{array}$ & 62 & $\begin{array}{c}69 \% \\
\text { (of } 90)\end{array}$ & 150 & $\begin{array}{c}77 \% \\
\text { (of } 196 \text { ) }\end{array}$ \\
\hline $\begin{array}{l}\text { With homologs in the } \\
\text { entire Opisthokonta }\end{array}$ & 27 & $\begin{array}{l}96.5 \% \\
\text { (of } 72 \text { ) }\end{array}$ & 57 & $\begin{array}{l}95 \% \\
\text { (of } 60 \text { ) }\end{array}$ & 60 & $\begin{array}{l}97 \% \\
\text { (of } 60 \text { ) }\end{array}$ & 144 & $\begin{array}{c}96 \% \\
\text { (of } 150 \text { ) }\end{array}$ \\
\hline $\begin{array}{l}\text { With homologs in } \\
\text { Holomycota only }\end{array}$ & 1 & $\begin{array}{l}3.5 \% \\
\text { (of } 72 \text { ) }\end{array}$ & 3 & $\begin{array}{l}5 \% \\
\text { (of } 60 \text { ) }\end{array}$ & 2 & $\begin{array}{l}3 \% \\
\text { (of } 60 \text { ) }\end{array}$ & 6 & $\begin{array}{c}4 \% \\
\text { (of } 150 \text { ) }\end{array}$ \\
\hline $\begin{array}{l}\text { Without homologs in } \\
\text { the } \mathrm{P} \text {. tribonematis } \\
\text { transcriptome }\end{array}$ & 8 & $\begin{array}{l}22 \% \\
\text { (of } 36 \text { ) }\end{array}$ & 10 & $\begin{array}{l}14 \% \\
\text { (of } 70)\end{array}$ & 28 & $\begin{array}{l}31 \% \\
\text { (of } 70)\end{array}$ & 46 & $\begin{array}{c}23 \% \\
\text { (of } 196)\end{array}$ \\
\hline $\begin{array}{l}\text { With homologs in the } \\
\text { entire Opisthokonta }\end{array}$ & 4 & $\begin{array}{l}50 \% \\
\text { (of } 8 \text { ) }\end{array}$ & 1 & $\begin{array}{l}10 \% \\
\text { (of } 10 \text { ) }\end{array}$ & 7 & $\begin{array}{l}25 \% \\
\text { (of } 28 \text { ) }\end{array}$ & 12 & $\begin{array}{c}26 \% \\
\text { (of } 46 \text { ) }\end{array}$ \\
\hline $\begin{array}{l}\text { With homologs in } \\
\text { Fungi only }\end{array}$ & 4 & $\begin{array}{l}50 \% \\
\text { (of } 8 \text { ) }\end{array}$ & 9 & $\begin{array}{c}90 \% \\
(\text { of } 10)\end{array}$ & 21 & $\begin{array}{c}75 \% \\
\text { (of } 28 \text { ) }\end{array}$ & 34 & $\begin{array}{c}74 \% \\
\text { (of } 46)\end{array}$ \\
\hline $\begin{array}{l}\text { Total with homologs } \\
\text { in the entire } \\
\text { Opisthokonta }\end{array}$ & 31 & $\begin{array}{l}86 \% \\
\text { (of } 36 \text { ) }\end{array}$ & 58 & $\begin{array}{l}83 \% \\
\text { (of } 70)\end{array}$ & 67 & $\begin{array}{l}75 \% \\
\text { (of } 90 \text { ) }\end{array}$ & 156 & $\begin{array}{c}80 \% \\
\text { (of } 196)\end{array}$ \\
\hline $\begin{array}{l}\text { Total with homologs } \\
\text { in Holomycota }\end{array}$ & 1 & $\begin{array}{c}3 \% \\
\text { (of } 36 \text { ) }\end{array}$ & 3 & $\begin{array}{c}4 \% \\
\text { (of } 70)\end{array}$ & 2 & $\begin{array}{c}2 \% \\
\text { (of } 90 \text { ) }\end{array}$ & 6 & $\begin{array}{c}3 \% \\
\text { (of } 196 \text { ) }\end{array}$ \\
\hline $\begin{array}{l}\text { Total with homologs } \\
\text { in Fungi only }\end{array}$ & 4 & $\begin{array}{l}11 \% \\
\text { (of } 36)\end{array}$ & 9 & $\begin{array}{l}13 \% \\
\text { (of } 70)\end{array}$ & 21 & $\begin{array}{l}23 \% \\
\text { (of } 90)\end{array}$ & 34 & $\begin{array}{c}17 \% \\
\text { (of } 196 \text { ) }\end{array}$ \\
\hline
\end{tabular}

chromosomes: one controls telomerase activity and other is related with DNA replication. Two genes $(5.5 \%)$ have transport functions. The products or activity results of four genes (each, $2.5 \%$ ) that were not united in the common functional group are: heat shock protein, broad-spectrum regulatory protein, vesicular transport and lipid biosynthesis. Expression of the last gene increased by six times, that is, more than all the others, showing maximum expression at 60 minutes. The functions of five genes (14.5\%) remain unknown.

Among genes with maximum expression at 120 min, 70 genes had $>1.5$ times increased expression level. From the 70 genes, 21 genes $(30 \%)$ control the processes associated with the synthesis and maturation mostly of the cytoskeletal and motor proteins. In this group, two genes are associated with the general processes of protein synthesis and folding; eight genes encoded actin, myosin and special proteins participating in actin-myosin complex folding; 11 genes encode the proteins of the tubulin-dynein complex, including genes of a specific axonemal dynein.
Thirteen genes (18.5\%) with maximal expression at 120 minutes encode regulatory and signaling proteins, most of which regulate enzymatic activity. Eight genes $(11.5 \%)$ control vesicular transport. Five genes $(7 \%)$ encode proteins associated with transmembrane ion transport. Five genes (7\%) are involved in metabolic processes: two in carbohydrate metabolism, one in coenzyme binding and two are associated with mitochondria. Four genes (6\%) are associated with protease cleavage. One gene (1.5\%) encodes a DNA polymerase, and one (1.5\%) encodes a cellular antioxidant. The functions of 12 genes (17\%) are unknown.

In a set of 155 genes with maximum expression at 150 minutes, 90 genes had $>1.5$ times increased expression level. In this group, 29 genes (32\%) are signaling or regulatory. Many of them are associated with known signaling pathways (NF- $\mathrm{B}$, Hippo), which in multicellular animals are involved in regulating cell proliferation, differentiation or apoptosis. Ten genes $(11 \%)$ control metabolic processes: three have a wide effect on metabolic processes, one affects lipid metabolism and can affect signaling associated 
Table 3. Functional groups of genes with increased expression by $\geq 1.5$ times selected from genes with maximum expression at 60 minutes of zoospore production. Bold font indicates the presence of homologs in the entire Opisthokonta; regular font indicates the presence of homologs only in the Holomycota or in Fungi exclusively.

\begin{tabular}{|l|l|}
\hline \multicolumn{1}{|c|}{ Sequence ID } & \multicolumn{1}{c|}{ Protein function } \\
\hline $\begin{array}{l}\text { BeE30N14B02, BeG90N22C02, BeE60N15C03, BeE60H26C08, BeE60N14C07, } \\
\text { BeE60N02F11, BeE120N38C06, BeE30N15E12, BeE60H30E02, BeE60N10D10, } \\
\text { BeE60H17C06, BeE60N02A06, }\end{array}$ & Protein breakdown \\
\hline $\begin{array}{l}\text { BeE60N05B04, BeG90N03D07, BeG120N25A08, BeE30N11G06, BeE60H29D03, } \\
\text { BeG60N07F05 }\end{array}$ & $\begin{array}{l}\text { Protein (including actin and tubulin) } \\
\text { maturation, mRNA processing }\end{array}$ \\
\hline BeE30N04B04, BeE120N01E04, BeE90D16C06, BeE60C31E12, BeE30N17E08 & Redox balance, redox reactions \\
\hline BeE30N16B09, BeE60N18H09 & Affects chromosomes \\
\hline BeNSVP07B10, BeE120N03E08 & $\begin{array}{l}\text { Proton transport, creating an acidic } \\
\text { environment }\end{array}$ \\
\hline BeE60N04H05 & Regulatory protein \\
\hline BeE60N03G10 & Lipid biosynthesis \\
\hline BeG120N09B09 & Vesicular transport \\
\hline BeE60H14B07 & Heat shock protein \\
\hline BeE60N14B10, BeNSVP06B04, BeE90N12A05, BeE30N11D01, BeE60N01G04 & Unknown \\
\hline
\end{tabular}

with cell division, three are involved in carbohydrate metabolism, one is involved in the synthesis of cell membrane phospholipids, one maintains lysosome activity, and one participates in oxidative metabolic reactions. Five genes $(5.5 \%)$ are associated with protein synthesis and post-translational processing: two genes of ribosomal proteins, two genes involved in post-translational protein modification, one gene affects mRNA maturation. Five genes (5.5\%) are involved in chitin metabolism, three of which are chitin synthase genes. Five genes (5.5\%) are involved in transmembrane transport, three of which in the $\mathrm{ABC}$ system and one in transmembrane water transport. Four genes $(4.5 \%)$ control redox potential. Four genes $(4.5 \%)$ control actin filament assembly and depolymerization, i.e. the work of the cytoskeleton. Three genes (3.5\%) are involved in flagellar construction; the expression of one of them increased by 23.6 times. Four genes (4.5\%) are involved in nucleotide and nucleic acid reactions, one of them coding the DNA-repair protein. One gene $(1 \%)$ participates in vesicular transport. One gene $(1 \%)$ is a homolog of genes encoding a factor that promotes amyloid fibers formation in Metazoa. The functions of 19 genes $(21.5 \%)$ remain unknown, among which one gene had up to 37.5 times increased expression.

\section{Discussion}

\section{THREE PHASES OF ZOOSPOROGENESIS}

Based on our gene activity analyses we have identified the three observed time points of the original study (Vieira and Gomes, 2013) as the three different phases of cellular morphogenesis in multinuclear sporangium.

1) The switching phase (60 minutes point). Apparently, at this stage, the sporangial cell switches from a trophic mode of activity to zoospore production. At this stage the main group of expressed genes is responsible for proteasome action and protein destruction. This finding is consistent with the available data on the key role of protease activity causing destruction of specific inhibitors of zoosporogenesis at the beginning of B. emersonii zoospore production (Correa et al., 1978). However, the increased production of proteasomes suggests that there could be a massive destruction of structural proteins and enzymes of the vegetative stage. Such a suggestion is also consistent with known observations on B. emersonii by Lodi and Sonneborn (1974). It is likely that, at this stage, the cell enters a new mode of functioning, halting the enzymatic activity of the previous stage. A pronounced stoppage of enzymes of the vegetative stage may mean that this is caused 
Table 4. Functional groups of genes with $\geq 1.5$ times increased expression selected from genes with maximum expression at 120 minutes of zoospore production. Bold font indicates the presence of homologs in the entire Opisthokonta; regular font indicates the presence of homologs only in the Holomycota or in Fungi exclusively.

\begin{tabular}{|c|c|}
\hline Sequence ID & Protein function \\
\hline BeG90N20H10, BeE60N09A10 & Protein synthesis and folding \\
\hline $\begin{array}{l}\text { BeE120N38G07, BeE60N07E05, BeE120N30D02, BeE60H28B01, BeE60N12E01, } \\
\text { BeE60N16A06, BeE90D04C07, BeE60N10E10 }\end{array}$ & $\begin{array}{l}\text { Production of actin-myosin system } \\
\text { elements }\end{array}$ \\
\hline $\begin{array}{l}\text { BeE90D13B04, eE90N18A12, BeE30N08A11, BeE90N11D07, BeE90N23C08, } \\
\text { BeE90N15E030, BeE120N07A12, BeE90N17C06, BeE120N38D06, BeE60N12G09, } \\
\text { BeG120N22C04 }\end{array}$ & $\begin{array}{l}\text { Production of tubulin-dynein } \\
\text { system elements }\end{array}$ \\
\hline $\begin{array}{l}\text { BeE60N09H03, BeE3ON10H03, BeE60H25C12, BeE120N25H03, BeE120N32A12, } \\
\text { BeE90N13A10, BeE12ON06B11, BeE60N13H06, BeE60N03A04, BeG12ON09D05, } \\
\text { BeE60N12F10, BeE30N07B02, BeE90N18E01 }\end{array}$ & Different regulatory functions \\
\hline $\begin{array}{l}\text { BeE120N35H01, BeE60N08E08, BeE120N28H02, BeE60N08B06, BeE60N09D06, } \\
\text { BeE90N18B06, BeE60H27A03, BeE30N10H08 }\end{array}$ & Vesicular transport \\
\hline BeE60N07F01, BeE30N06A03, BeE120N26G05, BeE60N10B03, BeE60N18C09 & $\begin{array}{l}\text { Transmembrane ion transport, } \\
\text { creation of an acidic medium in } \\
\text { vacuoles }\end{array}$ \\
\hline BeG30N03G06, BeE120N07F05, BeE60H27E10, BeE60N16B11, BeE60H22A08 & Metabolism \\
\hline BeE60N08H03, BeE60C01E02, BeE120N08A01, BeE120N37H01 & Protein breakdown \\
\hline BeE120N22B08 & DNA polymerase \\
\hline BeE60N07E08 & Cell antioxidant \\
\hline $\begin{array}{l}\text { BeE30N14B04, BeE60N06C01, BeE60N07G07, BeE120N02A03, BeE12ON31H05, } \\
\text { BeE60N05D04, BeE90N04E09, BeE90N16C12, BeE120N03E07, BeE60N09H02, } \\
\text { BeE90N21E01, BeE60N05D09 }\end{array}$ & Unknown \\
\hline
\end{tabular}

not by the gradual accumulation of endogenous factors, but by the dramatic exogenous effect. This is in good agreement with the artificial induction of zoospore production by the chemical composition of the culture medium in experiments (Vieira and Gomes, 2013).

The second largest group of expressed genes is associated with protein synthesis. Most of these genes control the processing of $\mathrm{mRNA}$ and proteins. These genes can be involved in the synthesis and folding of the proteins actively working in this phase as parts of proteasomes. However, perhaps they are activated in advance to provide protein synthesis in the next phase.

The third group of expressed genes is involved in regulating the redox balance. The authors of the initial data noted the activation of the redox balance genes when tryptophan was added to the medium (Vieira and Gomes, 2013). However, apparently, a special adjustment of the redox balance is required in the first phase of zoosporogenesis even when it proceeds under normal conditions. It should be noted that, at this stage, there is no significant expression of signaling genes. This is consistent with assumptions that $B$. emersonii zoospore production regulation at the transcription level does not occur in the early stages, and that protein destruction itself may be a regulatory factor (Lodi and Sonneborn, 1974; da Silva et al., 1986). The effect of the redox potential as a signaling factor (redox signaling) is described in the literature (Requejo et al., 2010; Randall et al., 2013; Cui and Wang, 2018; Laurindo, 2018). In multicellular animals, redox signaling plays a large role in triggering certain cellular processes, for example, in preparing a cell for apoptosis (Zhang et al., 2014). It is possible that changes in the redox potential can also play a signaling role during early sporogenesis.

Two genes affecting DNA stability are possibly activated to prepare rapid production and maturation of RNA and proteins in the next phase, when signaling cascades and transcription factors are involved. Another feature of this phase of zoosporogenesis is a 6-fold increase in the activity of a gene associated with lipid metabolism. Whether its activation is associated with the accumulation of lipid droplets in zoospores is not yet known.

2) The synthesis and distribution phase (120 minutes). During this stage, the synthesis of motor and cytoskeletal proteins, components of both the 
Table 5. Functional groups of genes with $\geq 1.5$ times increased expression selected from genes with maximum expression at 150 minutes of zoospore production. Bold font indicates the presence of homologs in the entire Opisthokonta; regular font indicates the presence of homologs only in the Holomycota or in Fungi exclusively.

\begin{tabular}{|c|c|}
\hline Sequence ID & Protein function \\
\hline $\begin{array}{l}\text { BeE60N10H07, BeE60N16D02, BeE120N02E04, BeE60N07H08, BeE60H29D02, BeE120N36B05, BeE60N03C06, } \\
\text { BeZSPN16D09, BeG60N08H03, BeE60N18D05, BeE120N25C02, BeE60H23E05, BeE120N18F01, BeE90N24F09, } \\
\text { BeE120N04B04, BeG120N10E08, BeE120N28E07, BeE30N01C07, BeE60N04E11, BeE60H27A04, BeE120N30B12, } \\
\text { BeE120N26G06, BeG30N13H07, BeE90N12F11, BeE60H26C05, BeE120N28B11, BeE120N06A04, BeE120N02A09, } \\
\text { BeE60N05B05 }\end{array}$ & Signaling and regulation \\
\hline $\begin{array}{l}\text { BeE90N06H03, BeE120N26B11, BeE60H28F02, BeE120N01D10, BeE30N02B01, BeE120N36H09, BeE60N05D05, } \\
\text { BeE60N12E11, BeG60N07D09, BeE90D07E02 }\end{array}$ & Metabolic processes \\
\hline BeE120N07D10, BeE120N01E11, BeE90D20G12, BeE60H30F11, BeE90N10F09 & $\begin{array}{l}\text { Protein synthesis and folding } \\
\text { (including actin and tubulin) }\end{array}$ \\
\hline BeE30N13H09, BeZSPN14D10, BeE120N28C07, BeE60H27E01, BeE120N32H02 & Chitin metabolism \\
\hline BeE120N27C01, BeE120N05H04, BeE120N27G08, BeE60N19E10, BeE60N04B11 & Transmembrane transport \\
\hline BeE90N01E04, BeE120N28D07, BeE60H30C05, BeE60N07D05 & Redox balance, redox reactions \\
\hline BeG120N07D05, BeE90N02C04, BeE60H15H11, BeE90N21E02 & Actin and actin-based processes \\
\hline BeG60N12B02, BeZSPN15B04, BeG90N17F03, BeE90N07F09 & Nucleotide acids reactions \\
\hline BeE120N20H04, BeE120N28A06, BeE90D18C07 & Flagellum assembly, tubulin \\
\hline BeE60N05G06 & $\begin{array}{l}\text { Membrane protein, vesicular } \\
\text { transport }\end{array}$ \\
\hline BeE120N25B05 & Protein transformation \\
\hline $\begin{array}{l}\text { BeE120N38C11, BeE60N19C09, BeE120N22C08, BeE60C25D08, BeE120N25E05, BeE120N30G01, BeNSVP09G10, } \\
\text { BeZSPN17D01, BeE120N20C04, BeG60N06E08, BeG30N16C06, BeE60N10D02, BeE90N04D01, BeG30N14D11, } \\
\text { BeE120N27G03, BeE120N08G03, BeE120N32E07, BeE60N13A03, BeG120N14G12 }\end{array}$ & Unknown \\
\hline
\end{tabular}

actin-myosin and tubulin-dynein systems, cellular signaling and intracellular vesicular transport dominate. The increased activity of the genes that produce axonemal dynein specifically indicates the ongoing synthesis of flagellar components. Flagellar formation takes place at approximately $164 \mathrm{~min}$ during zoosporogenesis (Peralta and Lodi, 1988). Correspondingly zoosporangium cleavage must occur between 150 and 164 mins. It turns out that the activation of axonemal protein genes occurs at least 30 minutes before their use.

The regulatory roles of signaling proteins and protein cascades apparently increase dramatically at this stage. At the same time, the expression of genes associated with redox potential decreases sharply. Obviously, at this stage, the transition to regulation at the transcriptional level takes place (Vieira and Gomes, 2013). Many signal proteins involved in the process have homologs in multicellular animals where they are also involved in signaling processes.

The increased activity of the vesicular transport genes apparently coincides with the active formation of vacuoles in the sporangium. We cannot clearly identify the process requiring such membrane transport intensification. At the same time, the parallel expression of the vacuolar ATPase genes and other proton-transporting enzymes associated with the creation of an acidic environment occurs. Cellular proteinase activities are enhanced in B. emersonii sporulation (Lodi and Sonneborn, 1974). The increased proteinase activity peaks in the second half of sporulation and at the end of zoospore production. It is likely that increased vacuole production and the creation of an acidic environment are at least partially associated with the beginning of the accumulation of vacuolar and lysosomal proteinases and the creation of conditions for their action.

Amid the general decline in metabolic processes noted by Vieira and Gomes (2013), some genes associated with metabolism, on the contrary, are activated. Among the marked metabolic genes, two are associated with the mitochondria, and two are associated with carbohydrate metabolism. Probably, their expression is necessary for supplying energy to the ongoing processes. Along with the processes of 
synthesis and distribution, the enhanced proteasomal destruction of unnecessary proteins continues. It is likely, in the process of rapid change in the cell, there is a need to quickly remove structural proteins, and enzymes in order to complete this task in a specific period (da Silva et al., 1986).

During this phase we see an increase in the expression level of some DNA polymerases. It reaches a four-fold level compared with the basic level (that was defined as the expression level in the vegetative and not the sporulated stage (Vieira and Gomes, 2013)). The reason of this increase is not clear because nuclear division has taken place before zoospore production begins (Peralta and Lodi, 1988; Vieira and Gomes, 2013). Perhaps this fact reflects some reparation processes.

3) The setting phase is the phase occurring at 150 minutes after induction of zoosporulation (approximately 10 minutes before the appearance of zoospores). The main functional group of this period contains regulatory and signaling genes. Apparently, in this phase, there is a final 'tuning' of the system before transition to sporangial cell division and zoospore production.

To maintain ongoing processes, numerous metabolism-associated genes are activated, including those for lipid, carbohydrate and general metabolic processes, including oxidative metabolism. The notable activation of the phospholipid synthesis gene is probably associated with enhanced membrane synthesis for expected multiple cell division of sporangia that will occur after several minutes (near 163 minutes during sporulation) (Peralta and Lodi, 1988).

Some genes that control protein synthesis and folding are maximally expressed in this phase. It can be assumed that the products of these genes are involved in producing specific proteins confined to the same period. Most of the specific regulatory and signaling proteins have complex tertiary and quaternary structures, so the participation of proteins that ensure proper folding seems highly likely. At the same time, analogous to flagellar proteins, auxiliary proteins of protein synthesis can be produced for delayed use. During the final stage of zoospore production (150-200 minutes), numerous proteins are synthesized (da Silva et al., 1986). Perhaps their synthesis apparatus is prepared in advance.

Five actively expressed genes are associated with chitin metabolism, three of which are chitin synthase genes. Fungal zoospores lack cell walls; therefore, chitin synthase (or corresponding mRNA) obviously accumulates for the rapid development of the cell wall at the beginning of zoospore germination. Studies on protein synthesis during $B$. emersonii zoospore production have shown that proteins and mRNAs can be accumulated in zoospores for activity during germination (da Silva et al., 1986). As in the situation with axonemal proteins, there is again a time lag between gene expression and the usage of the gene product.

Compared to the previous phase, more genes regulating redox balance are expressed in this setting phase. The redox balance control could be an important factor affecting: the reactions associated with the cell proliferation, the works of regulatory proteins, or the control of the cell enzyme activities.

Four activating genes responsible for transmembrane transport belong to the family of ABC transporters, which in eukaryotes are most often used in substance excretion from the cell to the outside (Wilkens, 2015). Perhaps unnecessary, hard-toutilize substances and metabolic products are discarded from the cell before division and the final formation of zoospores. It is also possible, that $\mathrm{ABC}$ transporters could function within intracellular membranes and participate in some actions within the membrane-containing organelles (e.g. into Golgi apparatus).

During the setting phase, actin and tubulin synthesis continues in the cell. Moreover, the genes of some proteins that play a role in actin filament assembly or depolymerization are expressed. Obviously, there is constant rearrangement of the actin cytoskeleton in connection with the cell cycle and cytokinesis processes. The expression of two genes affecting flagellar assembly is also increased, one by 23.6 times. This increase is logical considering that flagellar assembly would start within 10 minutes after this phase.

The expression of three genes controlling nucleotide metabolism may correlate with DNA polymerase synthesis. This synthesis is maximized in the previous synthesis and distribution phase but continues in the current phase. However, perhaps the activity of nucleotide metabolism genes is associated with the production of many mRNAs. The synthesis of mRNAs, which accumulate in zoospores and ensure their rapid germination, begins at approximately 150 minutes after zoosporogenesis induction (da Silva et al., 1986).

Additionally, during the setting phase, two transmembrane transport genes reach their maxi- 
mum expression. One of these is a water transport gene. Perhaps the formation of zoospores requires saturation of their cytoplasm with water.

Features of analyzed gene Set leading to the FURTHER EVOLUTIONARY STUDIES

Zoosporogenesis is initially triggered by exogenous factors probably changing the redox potential. The number of expressed signaling and regulatory genes increases throughout zoosporogenesis.

Many of the signaling and regulatory genes, especially of the third phase, have homologs that play a significant role in regulating cell development and differentiation in Metazoa. As zoosporogenesis is also the process of the cell production and differentiation, one can propose that these genes are derived from the ancestral genes regulating cell proliferation and differentiation in a common opisthokont ancestor. Therefore, the presence of cellular transformations in the opisthokont ancestor and the involvement of corresponding genetic machinery in multicellularity appearance can be assumed. It could be useful to study the distribution and functions of these noted genes within the unicellular Opisthokonta.

For example, the presence of gene homologs of the Hippo signaling regulatory cascade among the regulatory genes of the second and third phases is noteworthy. In multicellular animals, this signaling pathway is involved in cell proliferation and apoptosis. Genes and probably some chains of the Hippo signaling cascade are present in holozoan unicellular relatives of Metazoa (Sebé-Pedrós et al., 2012). However, the functions of the Hippo cascade elements in those organisms are still unknown. Consideration of $B$. emersonii zoosporogenesis shows that the Hippo signaling gene homologs are involved in morphogenetic processes in Holomycota also. Thus, it can be assumed that the Hippo signaling cascade, or its precursor, was a part of the machinery in the morphogenetic processes in a common opisthokont ancestor. In this light, it would be interesting to trace the presence and functions of Hippo cascade elements in different lineages of the Opisthokonta tree.

It is also noteworthy that a few signaling and regulatory genes involved in zoosporogenesis have homologs involved in preparing cells for apoptosis in Metazoa. The same is applicable to the genes of redox balance and redox signaling. Perhaps apoptosis, as an integral controlled process, arose in
Metazoa on the basis of a previous morphogenetic process, which performed a different function in unicellular ancestor.

One more notable feature in B. emersonii zoosporogenesis is the pronounced time gap between the production of some proteins and the time of their usage. Possibly, this phenomenon could facilitate another way of cell process regulation by fast switching from one cell condition to another by activating and using previously stored proteins.

In general, the function of $18 \%$ of the valid analyzed genes remain unknown (Table 6). For many of these genes the expression levels increased significantly during zoosporogenesis. For instance, the expression of one gene peaked at setting phase by increasing 37 times (Table 5). That is, these genes with unknown functions must have significant functions. At the recorded time intervals $(60,120$ and $150 \mathrm{~min})$ the proportion of genes with unknown functions changed with the following dynamics: $14 \%$ to $17 \%$ to $21 \%$ (Table 6). Thus, their proportion increased from first phase to third one and was maximal in the "settings phase". Most of the genes with unknown functions (81\%) are specifically fungal genes, without homologs in other Opisthokonta, such as in Holozoa as well as other Holomycota. Therefore, these genes could possibly encode specifically fungal structural proteins and enzymes. They also can be specific regulators that direct the course of processes universal for Opisthokonta in the context of the zoospore morphogenesis characteristic of zoospore fungi. In this case, their increased influence in the setting phase becomes especially noteworthy.

Comparison of THE ANALYZED GENE SET WITH THE $P$. TRIBONEMATIS TRANSCRIPTOME HYPOTHESIZES AN INDEPENDENT LIFE CYCLE ORIGIN IN FungI AND APHELIDA

Comparison of the set of B. emersonii genes, which increase expression during sporogenesis, with the $P$. tribonematis transcriptome showed that $77 \%$ of noted B. emersonii genes have aphelid homologs (Table 1). The general share of genes without aphelid homologs is $23 \%$. When considering the three noted phases separately, it can be seen that from phase to phase the share of genes without aphelid homologs changes. From the first to second phase of zoosporogenesis production, the proportion of genes without aphelid homologs decreased slightly, and then sharply doubled on entering the third phase.

Among analyzed genes, that have no homologs in P. tribonematis, the $26 \%$ of genes have homologs 
Table 6. The numbers and proportions of proteins with known and unknown functions, and the numbers and proportions of genes with homologs in different lineages among them.

\begin{tabular}{|c|c|c|c|c|c|c|c|c|}
\hline \multirow{3}{*}{$\begin{array}{l}\text { Described } \\
\text { sequences }\end{array}$} & \multicolumn{2}{|c|}{$60 \mathrm{~min}$} & \multicolumn{2}{|c|}{$120 \mathrm{~min}$} & \multicolumn{2}{|c|}{$150 \mathrm{~min}$} & \multicolumn{2}{|c|}{ Total } \\
\hline & Number & Percentage & Number & Percentage & Number & Percentage & Number & Percentage \\
\hline & 36 & & 70 & & 90 & & 196 & \\
\hline $\begin{array}{l}\text { Total known } \\
\text { functions }\end{array}$ & 31 & $\begin{array}{c}86 \% \\
\text { (of } 36)\end{array}$ & 58 & $\begin{array}{c}83 \% \\
\text { (of } 70)\end{array}$ & 71 & $\begin{array}{c}79 \% \\
\text { (of } 90 \text { ) }\end{array}$ & 160 & $\begin{array}{c}82 \% \\
\text { (of } 196)\end{array}$ \\
\hline $\begin{array}{l}\text { With homologs } \\
\text { in the entire } \\
\text { Opisthokonta }\end{array}$ & 30 & $\begin{array}{l}97 \% \\
\text { (of } 31 \text { ) }\end{array}$ & 57 & $\begin{array}{l}98 \% \\
\text { (of } 58 \text { ) }\end{array}$ & 67 & $\begin{array}{l}94 \% \\
\text { (of } 71 \text { ) }\end{array}$ & 154 & $\begin{array}{c}96 \% \\
\text { (of } 160 \text { ) }\end{array}$ \\
\hline $\begin{array}{l}\text { With homologs in } \\
\text { Holomycota }\end{array}$ & 1 & $\begin{array}{l}3 \% \\
\text { (of } 31 \text { ) }\end{array}$ & 1 & $\begin{array}{c}2 \% \\
\text { (of } 58 \text { ) }\end{array}$ & 1 & $\begin{array}{l}1,5 \% \\
\text { (of } 71 \text { ) }\end{array}$ & 3 & $\begin{array}{c}2 \% \\
\text { (of } 160 \text { ) }\end{array}$ \\
\hline $\begin{array}{l}\text { With homologs in } \\
\text { Fungi only }\end{array}$ & & & & & 3 & $\begin{array}{l}4,5 \% \\
\text { (of } 71 \text { ) }\end{array}$ & 3 & $\begin{array}{c}2 \% \\
\text { (of } 160 \text { ) }\end{array}$ \\
\hline $\begin{array}{l}\text { Total unknown } \\
\text { functions }\end{array}$ & 5 & $\begin{array}{c}14 \% \\
\text { (of } 36)\end{array}$ & 12 & $\begin{array}{c}17 \% \\
\text { (of } 36)\end{array}$ & 19 & $\begin{array}{c}21 \% \\
\text { (of } 90)\end{array}$ & 36 & $\begin{array}{c}18 \% \\
\text { (of } 196 \text { ) }\end{array}$ \\
\hline $\begin{array}{l}\text { With homologs } \\
\text { in the entire } \\
\text { Opisthokonta }\end{array}$ & 1 & $\begin{array}{l}20 \% \\
\text { (of } 5 \text { ) }\end{array}$ & 2 & $\begin{array}{l}17 \% \\
\text { (of } 12 \text { ) }\end{array}$ & 1 & $\begin{array}{l}5 \% \\
\text { (of } 19)\end{array}$ & 4 & $\begin{array}{l}11 \% \\
\text { (of } 36)\end{array}$ \\
\hline $\begin{array}{l}\text { With homologs in } \\
\text { Holomycota }\end{array}$ & & & 2 & $\begin{array}{l}17 \% \\
\text { (of } 12 \text { ) }\end{array}$ & 1 & $\begin{array}{l}5 \% \\
\text { (of } 19 \text { ) }\end{array}$ & 3 & $\begin{array}{c}8 \% \\
\text { (of } 36 \text { ) }\end{array}$ \\
\hline $\begin{array}{l}\text { With homologs in } \\
\text { Fungi only }\end{array}$ & 4 & $\begin{array}{l}80 \% \\
\text { (of } 5 \text { ) }\end{array}$ & 8 & $\begin{array}{c}66 \% \\
\text { (of } 12)\end{array}$ & 17 & $\begin{array}{c}90 \% \\
\text { (of } 19)\end{array}$ & 29 & $\begin{array}{l}81 \% \\
\text { (of } 36)\end{array}$ \\
\hline
\end{tabular}

in other lineages of Opisthokonta (Table2). These genes could be lost in Aphelida. The other $74 \%$ of genes without homologs in $P$. tribonematis have homologs exclusively in the Fungi (Table 2). These genes probably could have emerged after division of the fungal and aphelid lineages.

A comparison with all opisthokonts shows that $81 \%$ of analyzed genes have homologs in the entire Opisthokonta (both in holomycotan and holozoan lineages). The remaining $19 \%$ of genes have homologs in holomycotan lineages but not in holozoans. Among them $3 \%$ of genes have homologs in Fungi as well as in other Holomycota (i.e. P. tribonematis), and $16 \%$ of genes are specific exclusively to the Fungi (Table 2).

This fact means that the main part of gene machinery operating in B. emersonii zoosporogenesis comprises the universal eukaryotic and opisthokont genes. The proportion of exclusively fungal genes turns out to be much smaller, but still quite noticeable. However, the proportion of genes common to Holomycota (without Holozoa) is extremely small. Such gene distribution can have two possible explanations.

First, the complete life cycle with a specialized dispersal stage was already present in the common opisthokont ancestor, and it was subsequently modified during evolution of each descendant lineage. Such a proposition could have some support in the existence of the complex life cycle in basal Holozoa (Pekkarinen, 2003; Torruella et al., 2015). However, closer to the crown of the Holozoa tree, some species do not have obvious specializations but have a wide range of interconverting life forms and a variety of trophic strategies (Tikhonenkov et al., 2020). Therefore, the existence of a complex life cycle with specialized stages does not appear obvious for the opisthokont ancestor.

The second explanation is more probable: the common holomycotan ancestor could be a polymorphic organism like some recent unicellular Holozoa (Syssomonas multiformis, Pigoraptor spp.) (Tikhonenkov et al., 2020), which can irregularly transform from flagellated to amoeboid form and vice versa depending on environmental conditions. Further, the complex life cycle with the high specialization of different stages (such as losing the trophic function in flagellated cells) formed independently in the fungal and aphelid lineages. The distribution of analyzed genes should correspond to the observed one: the main part is inherited from a common ancestor, and a smaller, but significant part is specific for the particular fungal lineage. This assumption is consistent with many data on the widespread convergent evolution in the fungal lineage and the convergent appearance 
of various life forms and life cycles (Brun and Silar, 2010; Malagnac et al., 2008; Nagy et al., 2018).

This proposition can be examined by studying the genetic machinery involved in zoospore production in Aphelida and other lineages of Holomycota.

\section{Acknowledgments}

The research was supported by the Russian Science Foundation (project no. 16-14-10302). We also thanks the laboratory infrastructure of ZIN RAS programs AAAA-A19-119031200042-9 and AAAA-A19-119020690109-2. We thank Research Resource Center for Molecular and Cell Technologies (RRC MCT) at St. Petersburg State University and Research Resource Center of Novosibirsk department of RAS for assistance in molecular and bioinformatics research. We thank V. Zlatogursky, I. Pchelin, D. Tikhonenkov and our colleagues from the Invertebrate zoology department of SPbSU for scientific discussion, and Dr. B.S.C. Leadbeater in particular for correction of the English.

\section{References}

Adl S.M., Bass D., Laned C.E., Lukes J., Schoch C.L., Smirnov A., et al. 2019. Revisions to the classification, nomenclature, and diversity of eukaryotes. J. Eukar. Microbiol. 66, 4-119.

Brun S. and Silar P. 2010. Convergent evolution of morphogenetic processes in Fungi. In: Evolutionary biology - Concepts, molecular and morphological evolution (Ed.: Pontarotti P.). Springer, Berlin, Heidelberg, pp. 317-328. doi: 10.1007/ 978-3-642-12340-5_19.

Brunet T. and King N. 2017. The origin of animal multicellularity and cell differentiation. Dev Cell. 43 (2), 124-140. doi: 10.1016/j.devcel.2017.09.016.

Burkhardt P. 2015. The origin and evolution of synaptic proteins - choanoflagellates lead the way. J. Exp. Biol. 218, 506-514. doi: 10.1242/jeb.110247.

Cai X. 2008. Unicellular $\mathrm{Ca}^{2+}$ signaling 'toolkit' at the origin of metazoan. Mol. Biol. Evol. 25, 13571361. doi: $10.1093 / \mathrm{molbev} / \mathrm{msn} 077$.

Correa J.U., Lemos E.M. and Lodi W.R. 1978. Inhibition of sporulation in the water mold Blastocladiella emersonii by antipain. Dev. Biol. 66 (2), 470-479. doi: 10.1016/0012-1606(78)90252-X.

Cui T. and Wang X. 2018. Chapter 3 - Interplay among oxidative stress, redox signaling, ER stress, autophagy, and protein ubiquitylation in cardiometabolic disorders. In: Autophagy and cardiometabolic diseases. From molecular mechanisms to translational medicine (Eds: Ren J., Sowers J.R. and Zhang Y.). Academic Press, New York, pp. 29-42. doi: 10.1016/B978-0-12-805253-2.00003-1.

da Silva A.M., da Costa Maia J.C. and Juliani M.H. 1986. Developmental changes in translatable RNA species and protein synthesis during sporulation in the aquatic fungus Blastocladiella emersonii. Cell Differentiation. 18 (4), 263-274. doi: 10.1016/ 0045-6039(86)90058-8

de Mendoza A., Sebé-Pedrós A., Šestak M.S., Matejčić M., Torruella G., Domazet-Lošo T. and Ruiz-Trillo I. Transcription factor evolution in eukaryotes and the assembly of the regulatory toolkit in multicellular lineages. PNAS. 110 (50) E4858E4866. doi: 10.1073/pnas.1311818110.

Fairclough S.R., Chen Z., Kramer E., Zeng Q., Young S., Robertson H.M., Begovic E., Richter D.J., Russ C., Westbrook M.J., Manning G., Lang B. F., Haas B., Nusbaum C. and King N. 2013. Premetazoan genome evolution and the regulation of cell differentiation in the choanoflagellate $\mathrm{Sal}$ pingoeca rosetta. Genome Biol. 14, R15. doi: 10.1186 /gb-2013-14-2-r15.

King N. 2003. Evolution of key cell signaling and adhesion protein families predates animal origins. Science. 301 (5631), 361-363. doi: 10.1126/ science. 1083853

King N., Westbrook M., Young S., Kuo A., Abedin M., et al. 2008. The genome of the choanoflagellate Monosiga brevicollis and the origin of metazoans. Nature. 451, 783-788. doi: 10.1038/nature 06617.

Laurindo F.R. M., Liberman M., Fernandes D.C. and Leite P.F. 2018. Chapter 8- Endotheliumdependent vasodilation: nitric oxide and other mediators. In: Endothelium and cardiovascular diseases. Vascular biology and clinical syndromes (Eds: Da Luz P.L., Libby P., Chagas C.P. and Laurindo F. R. M.). Academic Press, New York, pp. 97-113. doi: 10.1016/B978-0-12-812348-5.00008-8.

Lodi W.R. and Sonneborn D.R. 1974. Protein degradation and protease activity during the life cycle of Blastocladiella emersonii. J Bacteriol. 117 (3), 1035-1042.

Malagnac F., Bidard F., Lalucque H., Brun S., Lambou K., Lebrun M.-H. and Silar P. 2008. Convergent evolution of morphogenetic processes in fungi. Commun. Integr. Biol. 1(2), 180-181. doi: 10.4161/cib.1.2.7198. 
Mikhailov K.V., Konstantinova A.V., Nikitin M.A., Troshin P.V., Rusin L.Yu., Lyubetsky V.A., et al. 2009. The origin of Metazoa: a transition from temporal to spatial cell differentiation. BioEssays. 31, 758-768. doi: 10.1002/bies.200800214.

Nagy L.G., Kovács G.M. and Krizsán K. 2018. Complex multicellularity in fungi: evolutionary convergence, single origin, or both? Biol. Rev. Camb. Philos. Soc. 93 (4):1778-1794. doi: 10.1111/brv. 12418.

Nichols S.A., Roberts B.W., Richter D.J., Fairclough S.R. and King N. 2012. Origin of metazoan cadherin diversity and the antiquity of the classical cadherin/ $\beta$-catenin complex. PNAS. 109 (32) 13046-13051. doi: 10.1073/pnas.1120685109.

Niklas K.J. and Newman S.A. 2013. The origins of multicellular organisms. Evol. Dev. 15 (1), 41-52. doi: 10.1111/ede. 12013.

Pekkarinen M., Lom J., Murphy C. A., Ragan M.A. and Dyková I. 2003. Phylogenetic position and ultrastructure of two Dermocystidium species (Ichthyosporea) from the common perch (Perca fluviatilis). Acta Protozool. 42, 287-307.

Peralta R.M. and Lodi W.R. 1988. An analysis of developmental timing in Blastocladiella emersonii sporulation. Dev. Biol. 128 (1), 78-85. doi: 10.1016/ 0012-1606(88)90269-2.

Randall L.M., Ferrer-Sueta G. and Denicola A. 2013. Chapter 3 - Peroxiredoxins as preferential targets in $\mathrm{H}_{2} \mathrm{O}_{2}$-induced signaling. Methods in Enzymology. 527, 41-63. doi: 10.1016/B978-0-12405882-8.00003-9.

Requejo R., Chouchani E.T., Hurd T.R., Menger K.E., Hampton M.B. and Murphy M.P. 2010. Measuring mitochondrial protein thiol redox state. Methods in Enzymology. 474, 123-147. doi: 10.1016/S0076-6879(10)74008-8.

Ruiz-Trillo I., Burger G., Holland P.W.H., King N., Lang B.F., Roger A.J. and Gray M.W. 2007. The origins of multicellularity: a multi-taxon genome initiative. Trends Genet. 23 (3), 113-118. doi: 10.1016/j.tig.2007.01.005.

Schulze K.L., Littleton J.T., Salzberg A., Halachmi N., Stern M., Lev Z. and Bellen H.J. 1994 . Rop, a Drosophila homolog of yeast Sec1 and vertebrate n-Sect/Munc-18 proteins, is a negative regulator of neurotransmitter release in vivo. Neuron. 13, 1099-1108. doi: 10.1016/0896-6273 (94)90048-5.

Sebé-Pedrós A., Degnan B.M. and RuizTrillo I. 2017. The origin of Metazoa: a unicellular perspective. Nature Rev. Genet. 18, 498-512.
Sebé-Pedrós A., Irimia M., del Campo J., Parra-Acero H., Russ C., Nusbaum C., Blencowe B.J. and Ruiz-Trillo I. 2013. Reulated aggregative multicellularity in a close unicellular relative of metazoa. eLife 2:e01287. doi: 10.7554/eLife.01287.

Sebé-Pedrós A., Roger A., Lang F., King N. and Ruiz-Trillo I. 2010. Ancient origin of the integrinmediated adhesion and signaling machinery. PNAS. 107, 10142-10147. doi: 10.1073/pnas.1002257107.

Sebé-Pedrós A., Zheng Y., Ruiz-Trillo I. and Pan D. 2012. Premetazoan origin of the Hippo signaling pathway. Cell Rep. 1 (1), 13-20. doi: 10.1016/ j.celrep.2011.11.004.

Staps M., van Gestel J. and Tarnita C.E. Emergence of diverse life cycles and life histories at the origin of multicellularity. Nat. Ecol. Evol. 3, 11971205. doi: 10.1038/s41559-019-0940-0.

Tikhonenkov D.V., Hehenberger E., Esaulov A.S., Belyakova O.I., Mazei Y.A., Mylnikov A.P. and Keeling P.J. 2020. Insights into the origin of metazoan multicellularity from predatory unicellular relatives of animals. BMC Biol. 18, 39. https://doi.org/10.1186/s12915-020-0762-1.

Torruella G., De Mendoza A., Grau-Bove X., Anto M., Chaplin M. A., Del Campo J., et al. 2015. Phylogenomics reveals convergent evolution of lifestyles in close relatives of animals and fungi. Curr. Biol. 25 (18), 2404-2410.

Torruella G., Grau-Bové X., Moreira D., Karpov S.A., Burns J.A., Sebé-Pedrós A., Völcker E. and López-García P. 2018. Global transcriptome analysis of the aphelid Paraphelidium tribonematis supports the phagotrophic origin of fungi. Commun. Biol. 1, 231. doi: 10.1038/s42003-018-0235-z.

van Gestel J. and Tarnita C.E. 2017. On the origin of biological construction, with a focus on multicellularity. PNAS. doi: 10.1073/pnas. 1704631114.

Vieira A.L.G. and Gomes S.L. 2013. Global gene expression analysis during sporulation of the aquatic fungus Blastocladiella emersonii. Eukaryot. Cell. 9 (3), 415-423. doi: 10.1128/EC.00312-09.

Wilkens S. 2015. Structure and mechanism of ABC transporters. F1000Prime Rep. 7, 14. https:// doi.org/10.12703/P7-14.

Zhang H., Du Y., Zhang X., Lu J. and Holmgren A. 2014. Glutaredoxin 2 reduces both thioredoxin 2 and thioredoxin 1 and protects cells from apoptosis induced by auranofin and 4-hydroxynonenal. Antioxid. Redox Signal. 21 (5), 669-681. https:// doi.org/10.1089/ars.2013.5499. 


\section{Supplementary materials}

Tables 3-5 (full versions). Functional groups of genes of B. emersonii increasing the expression by 1.5 or more times, the expression level and homology of B. emersonii and P. tribonematis genes.

Address for correspondence: Igor Pozdnyakov. Zoological Institute of Russian Academy of Science, Universitetskaya Emb. 1, St. Petersburg, 199034, Russia; e-mail: d_igor_po@yahoo.com . 